\title{
ANALISIS PERKEMBANGAN KEMAMPUAN KEUANGAN DAERAH DALAM MENDUKUNG PELAKSANAAN OTONOMI DAERAH DI KOTA BITUNG (PERIODE 2008-2012)
}

\author{
Juliet Marla Hetharia \\ Harijanto Sabiono \\ Inggriani Elim
}

\author{
Fakultas Ekonomi Jurusan Akuntansi \\ Universitas Sam Ratulangi Manado \\ Email : juliethetharia@yahoo.com
}

\begin{abstract}
ABSTRAK
Paradigma pengelolaan keuangan daerah, baik ditingkat provinsi maupun kabupaten/kota mengalami perubahan yang sangat berarti seiring dengan diterapkannya otonomi daerah. Dalam menjalankan otonomi daerah, Pemerintah Daerah dituntut untuk menjalankan roda pemerintahan yang efektif, efisien, dan mampu mendukung peran masyarakat dalam meningkatkan pemerataan dan keadilan dengan mengembangkan seluruh potensi yang dimiliki oleh masing-masing daerah. Kemampuan keuangan suatu daerah dapat dilihat dari besar kecilnya Pendapatan Asli Daerah (PAD) yang diperoleh daerah yang bersangkutan, dalam kaitannya dengan pemberian otonomi daerah. Adapun tujuan dari penelitian ini adalah untuk menganalisis kemampuan keuangan daerah Kota Bitung dalam rangka mendukung pelaksanaan otonomi daerah periode 2008-2012. Data yang digunakan adalah data sekunder. Metode analisis yang digunakan adalah dengan menghitung rasio-rasio keuangan daerah antara lain rasio kemandirian, rasio derajat desetralisasi fiskal, rasio keserasian, rasio indeks kemampuan rutin, rasio ketergantungan dan rasio pertumbuhan. Hasil penelitian menunjukkan (1) Rasio Kemandirian masih rendah, (2) Rasio Derajat Desentralisasi Fiskal masih kurang, (3) Rasio Keserasian masih rendahnya belanja pembangunan dibandingkan belanja rutin, (4) Rasio Indeks kemampuan Rutin sangat kurang, (5) Rasio Ketergantungan sangat tinggi dan (6) Rasio Pertumbuhan rata-rata positif dan negatif. Dari hasil penelitian dan hasil analisis data dapat ditarik kesimpulan bahwa tingkat kemampuan keuangan daerah Kota Bitung dalam mendukung pelaksanaan otonomi daerah untuk periode 2008-2012 dianggap kurang mampu.
\end{abstract}

Kata Kunci : Kemampuan Keuangan Daerah, Otonomi Daerah

\section{ABSTRACT}

The paradigm of local financial management, both at the provincil and district/city experienced a significant change in line with the imlementation of regionel autonomy. In undergoing decentralization, local goverments are required to run the goverment that is effective, efficient, and able to support the community's role in improving equity and justice by developing the full potential of each region by. Financial capacity of $n$ area can be seen from the size of local revenue obtained the relevant area, in relation tothe granting of regional autonomy. The purpose of this study is to analyze the financial ability Bitung city areas in order to support the implementation of regional autonomy period 2008-2012. The data used is secondary data. The analytical method used is to calculate the area of financial ratios, among others, independence ratio, the ratio of the degree of fiscal decentralization, harmony ratio, the rti of routine capability index, dependency ratio, and the ratio of growth. The results showed (1) Independency Ratio still low, (2) The Ratio of the Degree of Fiscal Decentralization is still lacking, (3) Harmony Ratio is still low compared to regular shopping development spending, (4) Routine Capability Index Ratio is very less, (5) Dependency Ratio is very high and (6) Average Growth Ratio of positive and negative. From the research and data analysis can be conclude that the level of fiscal capacity Bitung city in support of regional autonomy for the period 2008-2012 are considered underprivileged.

Keywords : Local Fiscal Capacity, Local Autonomy 


\section{PENDAHULUAN}

\section{Latar Belakang}

Paradigma pengelolaan keuangan daerah, baik ditingkat provinsi maupun kabupaten/kota mengalami perubahan yang sangat berarti seiring dengan diterapkannya otonomi daerah. Hal ini ditandai dengan diberlakukannya UU yang menyangkut otonomi ini, yaitu UU No. 32 tahun 2004 tentang Pemerintahan Daerah dan UU No. 33 tahun 2004 tentang Perimbangan Keuangan antara Pemerintah Pusat dan Pemerintah Daerah. Berlakunya kedua UU ini memberikan peluang lebih besar kepada daerah dalam mengoptimalkan potensi yang ada, baik menyangkut sumber daya manusia, dana maupun sumber daya kekayaan daerah lainnya.

Hakekat dari otonomi daerah adalah kewenangan yang lebih besar dalam pengurusan maupun pengelolaan daerah, termasuk didalamnya pengelolaan keuangan. Di era otonomi daerah ini, daerah diberikan kesempatan untuk mengelolah keuangan daerahnya sendiri dengan lebih otonom tanpa harus diatur oleh pemerintah pusat. Pemerintah daerah diharapkan semakin mandiri, mengurangi ketergantungan terhadap pemerintah pusat terkait dengan pembiayaan dan pengelolaan daerah. Berkenaan dengan hal itu, pemerintah daerah diharapkan semakin mendekatkan diri dalam berbagai kegiatan pelayanan publik guna meningkatkan tingkat kepercayaan publik.

Keberhasilan otonomi daerah tidak terlepas dari kemampuan dalam bidang keuangan. Oleh karena itu pemerintah daerah diharapkan dapat mengembangkan potensi daerahnya sendiri dan menggali sumber dana yang ada dan potensial guna mewujudkan peningkatan kesejahteraan warga masyarakatnya. Akibatnya mekanisme pembiayaan pelaksanaan otonomi daerah berubah yaitu diutamakan semaksimal mungkin berasal dari potensi penerimaan asli daerah baik melalui pajak daerah, retribusi daerah maupun dari laba Badan Usaha Milik Daerah (BUMD) dan penerimaan lain yang dianggap sah serta potensi penerimaan lain yang masih belum terjangkau oleh Pendapatan Asli Daerah (PAD).

Kemampuan keuangan suatu daerah dapat dilihat dari besar kecilnya Pendapatan Asli Daerah (PAD) yang diperoleh daerah yang bersangkutan, dalam kaitannya dengan pemberian otonomi daerah. PAD selalu dipandang sebagai salah satu indikator atau kriteria untuk mengukur ketergantungan suatu daerah kepada pusat.

Penelitian ini dilakukan untuk menganalisis kemampuan Kota Bitung menjadi daerah otonom dalam konsep kemampuan desentralisasi otonomi daerah, dibatasi pada aspek keuangan yang meliputi struktur dan pengesahan dalam menghitung rasio keuangan daerah yang meliputi: Pendapatan Asli Daerah (PAD), Sumber Pendapatan dari Pihak Ekstern, Total Penerimaan Daerah (TPD), Total Pengeluaran Rutin, Belanja Operasi, Belanja Modal, Dana Alokasi Umum (DAU), Dana Alokasi Khusus (DAK), dan bantuan-bantuan.

Berdasarkan latar belakang tersebut di atas, maka rumusan masalah dalam penelitian ini adalah "Bagaimana kemampuan keuangan daerah Kota Bitung dalam rangka mendukung pelaksanaan otonomi daerah periode 2008-2012?". Adapun tujuan yang ingin dicapai dalam penelitian ini adalah untuk menganalisis tingkat kemampuan keuangan daerah Kota Bitung dalam rangka mendukung pelaksanaan otonomi daerah periode 2008-2012.

\section{TINJAUAN PUSTAKA}

Pada umumnya akuntansi didefinisikan dengan melihat proses kegiatannya. Definisi akuntansi dilihat dari kegiatannya yang merupakan suatu proses pencatatan, penggolongan, peringkasan, pelaporan, dan penganalisasian data-data keuangan dari suatu organisasi atau perusahaan (Puwanti \& Nugraheni, 2001: 2). Pengertian Akuntansi Pemerintahan Daerah menurut PP No. 24 Tahun 2005 tentang Standar Akuntansi Pemerintahan adalah serangkaian prosedur manual maupun yang terkomputerisasi mulai dari pengumpulan data, pencatatan penggolongan, peringkasan, dan pelaporan posisi keuangan dan operasi keuangan pemerintah.

Perkembangan pada sektor pemerintahan dewasa ini menuntut dilaksanakannya pemberian informasi dan pengungkapan atas aktivitas dan kinerja finansial pemerintah daerah kepada berbagai pihak yang berkepentingan. Pemerintah baik pusat maupun daerah harus menjadi subyek pemberi informasi dalam rangka pemebuhan hak-hak publik yaitu: hak untuk tau, hak untuk diberi informasi, dan hak untuk didengar inspirasinya (Halim, 2007:29).

Menurut Peraturan Pemerintah No.105 Tahun 2000, keuangan daerah adalah semua hak dan kewajiban daerah dalam rangka penyelenggaraan pemerintah daerah yang dapat dinilai dengan uang termasuk di dalamnya segala bentuk kekayaan yang berhubunagn dengan hak dan kewajiban daerah tersebut, dalam kerangka anggaran pendapatan dan belanja daerah.

Berdasarkan UU No. 17 tahun 2003, disebutkan bahwa Anggaran Pendapatan dan Belanja Daerah (APBD) adalah rencana keuangan tahunan pemerintahan daerah yang disetujui oleh Dewan Perwakilan Rakyat Daerah (DPRD). Menurut Sugianto (2007:15) APBD disusun sesuai dengan kebutuhan penyelenggaraan pemerintah dan kemampuan pendapatan daerah yang ditetapkan setiap tahun dengan peraturan daerah. Proses penyusunan 
APBD pada dasarnya bertujuan untuk menyelaraskan kebijakan ekonomi makro dan sumber daya yang tersedia, juga mengalokasikan sumber daya secara tepat sesuai dengan kebijakan pemerintah dan mempersiapkan kondisi bagi pelaksanaan pengelolaan anggaran (Sigianto, 2007:16).

Yang dimaksud dengan Laporan realisasi anggaran pemerintah daerah adalah laporan yang menyajikan ikhtisar sumber, alokasi, dan pemakaian sumber daya ekonomi yang dikelola oleh pemerintah daerah, yang menggambarkan perbandingan antara realisasi dan anggaran dalam satu periode pelaporan. Anggaran pemerintah daerah adalah rencana kegiatan yang direpresentasikan dalam bentuk perolehan pendapatan dan belanja dalam satuan moneter.

Anggaran merupakan daokumen yang menggambarkan kondisi keuangan dari suatu organisasi yang meliputi informasi mengenai pendapatan, belanja, dan aktivitas, dan estimasi mengenai apa yang akan dilakukan organisasi di masa yang akan datang (Halim,2007:36). Anggaran sektor publik memiliki beberapa fungsi utama, yaitu: (1) sebagai alat perencanaan, (2) alat pengendalian, (3) alat kebijakan fiskal, (4) alat politik, (5) alat koordinasi dan komunikasi, (6) alat penilaian kinerja, (7) alat motivasi, dan (8) alat menciptakan ruang publik (Mardiasmo,2002:63).

Penerimaan Daerah adalah uang yang masuk ke kas daerah. Penerimaan Daerah dalam pelaksanaan desetralisasi terdiri atas Pendapatan dan Pembiayaan. Pendapatan Daerah adalah hak pemerintah daerah yang diakui sebagai penambah nilai kekayaan bersih dalam periode tahun bersangkutan. Pembiayaan adalah semua penerimaan yang perlu dibayar kembali dan/atau pengeluaran yang akan diterima kembali, baik pada tahun anggaran yang bersangkutan maupun pada tahun-tahun anggaran berikutnya (Nurlan,2009:42). Pendapatan Asli Daerah yang selanjutnya disingkat PAD adalah pendapatan yang diperoleh daerah yang dipungut berdasarkan peraturan daerah sesuai dengan peraturan perundang-undangan (Nurlan,2009:48).

Ciri utama yang menunjukkan suatu daerah mampu melaksanakan otonomi daerah adalah sebagai berikut (Natahiddin, 2001:167):

a. Kemampuan keuangan daerah, artinya daerah harus memiliki kewenangan dan kemampuan untuk menggali sumber-sumber keuangan, mengelola dan menggunakan keuangan sendiri yang cukup memadai untuk membiayai penyelenggaraan pemerintahannya.

b. Ketergantungan kepada bantuan pusat harus seminimal mungkin agar Pendapatan Asli Daerah (PAD) harus menjadi bagian sumber keuangan terbesar, yang didukung oleh kebijakan perimbangan keuangan pusat dan daerah, sehingga peranan pemerintah daerah menjadi lebih besar.

Pengertian otonomi daerah berdasarkan Undang-Undang Nomor 32 Tahun 2004 tentang Pemerintahan Daerah adalah hak, wewenang, dan kewajiban daerah otonom untuk mengatur dan mengurus sendiri urusan pemerintahan dan kepentingan masyarakat setempat sesuai dengan peraturan perundang-undangan (Nuansa Aulia, 2009:5). Menurut Mahmudi (2006:23) dalam buku Standar Akuntansi Pemerintahan, tujuan utama pelaksanaan otonomi dan desentralisasi fiskal adalah untuk menciptakan good governance, yaitu tata kelola pemerintahan yang baik yang ditandai dengan adanya transparansi, akuntabilitas publik, partisipasi, efisiensi dan efektivitas, serta penegakan hukum.

\section{METODE PENELITIAN}

Jenis penelitian ini termasuk jenis penelitian deskriptif dengan objek penelitian Pemerintah Kota Bitung. Dalam penelitian ini digunakan jenis data kuantitatif dan sumber data sekunder mengenai APBD di Kota Bitung tahun anggaran 2008-2012. Teknik pengumpulan data dengan cara dokumentasi dan observasi. Analisis data yang digunakan dalam penelitian ini adalah:

1. Rasio Kemandirian (RM)

Menurut Halim (2007:232), kemandirian keuangan daerah menunjukkan kemampuan pemerintah darah dalam membiayai sendiri kegiatan pemerintahan, pembangunan dan pelayanan kepada masyarakat yang telah membayar pajak dan retribusi sebagai sumber pendapatan yang diperlukan daerah. Rasio kemandirian dapat diformulasikan sebagai berikut:

2. Rasio Derajat Desentralisasi Fiskal (DDF) 
Menurut Tangkilisan (2007:83) dalam buku Manajemen Publik, tingkat kemandirian fiskal antara pemerintah pusat dan daerah dapat dipelajari dengan melihat besarnya DDF suatu daerah. Secara sederhana rasio ini dapat diformulasikan sebagai berikut:

3. Rasio Keserasian

Menurut Halim (2007:235-236), rasio ini menggambarkan bagaimana pemerintah daerah memprioritaskan alokasi dananya pada belanja rutin dan belanja pembangunan secara optimal. Secara sederhana rasio ini dapat diformulasikan sebagai berikut:

a.

b.

4. Rasio Indeks Kemampuan Rutin

Menurut Tangkilisan (2007:85), Derajat Desentralisasi Fiskal tercermin melalui angka IKR, yaitu proporsi antara Pendapatan Asli Daerah dengan pengeluaran rutin tanpa transfer dari pemerintah pusat. Indeks kemampuan rutin dihitung dengan rumus:

5. Rasio Ketergantungan

Menurut Mahmudi (2007:128), rasio ketergantungan keuangan daerah dihitung dengan cara membandingkan jumlah pendapatan transfer yang diterima oleh penerimaan daerah dengan total penerimaan daerah.

Rasio ini dirumuskan sebagai berikut:

6. Rasio Pertumbuhan

Ratio pertumbuhan (Growth Rasio) mengukur seberapa besar kemampuan pemerintah daerah dalam mempertahankan dan meningkatkan keberhasilan yang telah dicapai dari satu periode ke periode berikutnya (Halim, 2007:241). Rumus yang digunakan adalah:

Keterangan:

$\mathrm{P}_{\mathrm{n}} \quad$ : Data yang dihitung pada tahun ke-n

$\mathrm{P}_{\mathrm{o}} \quad$ : Data yang dihitung pada tahun ke-0

R : Pertumbuhan

Data : PAD, TPD, Belanja Rutin, Belanja Pembangunan

\section{HASIL PENELITIAN DAN PEMBAHASAN}

Pada tanggal 1 Januari 1918 Bitung diakui oleh Pemerintah Belanda sebagai suatu negeri, walaupun pengesahannya baru pada tanggal 1 Januari 1928 setelah dikeluarkan beslit oleh pemerintah. Secara geografis, Kota Bitung terletak pada posisi diantara 1023'23' - 10 35' 39' LU dan 12501'43'" - 125018'13', BT. Adapun hasil dari penelitian ini adalah sebagai berikut: 


\section{Rasio Kemandirian}

Perhitungan Rasio Kemandirian Kota Bitung Tahun Anggaran 2008-2012

\begin{tabular}{|c|c|c|c|c|c|c|}
\hline No & TA & $\begin{array}{c}\text { Pendapatan } \\
\text { Asli Daerah }\end{array}$ & $\begin{array}{c}\text { Sumber Pendapatan } \\
\text { dari Pihak Ekstern }\end{array}$ & Hasil & \% & $\begin{array}{c}\text { Pola } \\
\text { Hubungan }\end{array}$ \\
\hline 1 & 2008 & Rp. $17.392 .736 .281,93$ & Rp. $351.865 .142 .589,00$ & 0,0494 & 4,94 & Instruktif \\
\hline 2 & 2009 & Rp. $16.822 .773 .814,07$ & Rp. $390.247 .191 .102,00$ & 0,0431 & 4,31 & Instruktif \\
\hline 3 & 2010 & Rp. $18.763 .528 .960,85$ & Rp. $428.055 .869 .453,00$ & 0,0438 & 4,38 & Instruktif \\
\hline 4 & 2011 & Rp. $25.394 .063 .796,63$ & Rp. $465.242 .263 .856,00$ & 0,0545 & 5,45 & Instruktif \\
\hline 5 & 2012 & Rp. $38.435 .120 .911,59$ & Rp. 517.135.271.153,00 & 0,0743 & 7,43 & Instruktif \\
\hline \multicolumn{2}{|l}{ Rata-Rata } & Rp. 23.361.644.753,01 & Rp. 430.509.147.630,60 & $\mathbf{0 , 0 5}$ & $\mathbf{5 , 0 0}$ & Instruktif \\
\hline
\end{tabular}

Sumber: Data diolah, 2013

\section{Rasio Derajat Desenralisasi Fiskal}

\section{Perhitungan Rasio Derajat Desetralisasi Fiskal}

\begin{tabular}{|c|c|c|c|c|c|c|}
\hline No & TA & $\begin{array}{l}\text { Pendapatan } \\
\text { Asli Daerah }\end{array}$ & $\begin{array}{c}\text { Total } \\
\text { Pendapatan Daerah }\end{array}$ & Hasil & $\%$ & $\begin{array}{c}\text { Kemampuan } \\
\text { Keuangan Daerah }\end{array}$ \\
\hline 1 & 2008 & Rp. 17.392.736.281,93 & Rp. 369.257.878.870,93 & 0,0471 & 4,71 & Sangat Kurang \\
\hline 2 & 2009 & Rp. $16.822 .773 .814,07$ & Rp. 407.069.964.916,07 & 0,0413 & 4,13 & Sangat Kurang \\
\hline 3 & 2010 & Rp. $18.763 .528 .960,85$ & Rp. 446.819.398.413,85 & 0,0419 & 4,19 & Sangat Kurang \\
\hline 4 & 2011 & Rp. 25.394.063.796,63 & Rp. $490.636 .327 .652,63$ & 0,0517 & 5,17 & Sangat Kurang \\
\hline 5 & 2012 & Rp. 38.435.120.911,59 & Rp. 555.570.392.064,59 & 0,0691 & 6,91 & Sangat Kurang \\
\hline \multicolumn{4}{|c|}{ Rata-Rata } & $\mathbf{0 , 0 5 0 2}$ & 5,02 & Sangat Kurang \\
\hline
\end{tabular}

\section{Rasio Keserasian}

\section{Perhitungan Rasio Keserasian}

\begin{tabular}{|c|c|c|c|c|c|c|c|c|}
\hline No & TA & Total Belanja & $\begin{array}{c}\text { Total } \\
\text { Belanja Operasi }\end{array}$ & $\begin{array}{c}\text { Total } \\
\text { Belanja Modal }\end{array}$ & $\begin{array}{c}\text { Rasio } \\
\text { Belanja } \\
\text { Rutin } \\
\text { (Operasional) }\end{array}$ & $\%$ & $\begin{array}{c}\text { Rasio } \\
\text { Belanja } \\
\text { Pembangunan } \\
\text { (Modal) }\end{array}$ & $\%$ \\
\hline 1 & 2008 & Rp. $366.960 .420 .078,00$ & Rp. 287.386.205.855,00 & Rp. 78.762.098.123,00 & 0,7831 & 78,31 & 0,2740 & 27,4 \\
\hline 2 & 2009 & Rp. 397.263.093.216,60 & Rp. 298.977.031.703,60 & Rp. $96.790 .461 .513,00$ & 0,7525 & 75,25 & 0,3237 & 32,37 \\
\hline 3 & 2010 & Rp. 459.724.036.794,00 & Rp. 343.331.542.956,00 & Rp. 113.573.131.025,00 & 0,7468 & 74,68 & 0,3307 & 33,07 \\
\hline 4 & 2011 & Rp. 483.991.924.455,00 & Rp. 380.005.130.183,00 & Rp. 103.257.610.472,00 & 0,7851 & 78,51 & 0,2717 & 27,17 \\
\hline 5 & 2012 & Rp. 538.645.556.073,00 & Rp. $409.011 .702 .380,00$ & Rp. 129.165.574.193,00 & 0,7593 & 75,93 & 0,3157 & 31,57 \\
\hline \multicolumn{5}{|c|}{ Rata-Rata } & 0,765 & 76,5 & $\mathbf{0 , 3 0 3 2}$ & $\mathbf{3 0 , 3 2}$ \\
\hline
\end{tabular}

Sumber: Data diolah, 2013 


\section{Rasio Indeks Kemampuan Rutin}

\section{Perhitungan Rasio Indeks Kemampuan Rutin}

\begin{tabular}{|c|c|c|c|c|c|c|c|c|}
\hline No & TA & Total Belanja & $\begin{array}{c}\text { Total } \\
\text { Belanja Operasi }\end{array}$ & $\begin{array}{c}\text { Total } \\
\text { Belanja Modal }\end{array}$ & $\begin{array}{c}\text { Rasio } \\
\text { Belanja } \\
\text { Rutin } \\
\text { (Operasional) }\end{array}$ & $\%$ & $\begin{array}{c}\text { Rasio } \\
\text { Belanja } \\
\text { Pembangunan } \\
\text { (Modal) }\end{array}$ & $\%$ \\
\hline 1 & 2008 & Rp. $366.960 .420 .078,00$ & Rp. $287.386 .205 .855,00$ & Rp. 78.762.098.123,00 & 0,7831 & 78,31 & 0,2740 & 27,4 \\
\hline 2 & 2009 & Rp. 397.263.093.216,60 & Rp. 298.977.031.703,60 & Rp. $96.790 .461 .513,00$ & 0,7525 & 75,25 & 0,3237 & 32,37 \\
\hline 4 & 2011 & Rp. $483.991 .924 .455,00$ & Rp. $380.005 .130 .183,00$ & Rp. 103.257.610.472,00 & 0,7851 & 78,51 & 0,2717 & 27,17 \\
\hline 5 & 2012 & Rp. 538.645.556.073,00 & Rp. $409.011 .702 .380,00$ & Rp. 129.165.574.193,00 & 0,7593 & 75,93 & 0,3157 & 31,57 \\
\hline \multicolumn{5}{|c|}{ Rata-Rata } & 0,765 & 76,5 & $\mathbf{0 , 3 0 3 2}$ & 30,32 \\
\hline
\end{tabular}

Sumber: Data diolah, 2013

\section{Rasio Ketergantungan}

\section{Perhitungan Rasio Ketergantungan}

\begin{tabular}{|c|c|c|c|c|c|c|}
\hline No & TA & $\begin{array}{l}\text { Pendapatan } \\
\text { Transfer }\end{array}$ & $\begin{array}{c}\text { Total } \\
\text { Pendapatan Daerah }\end{array}$ & Hasil & $\%$ & Kemampuan Keuangan \\
\hline 1 & 2008 & Rp. 345.365.142.589,00 & Rp. $369.257 .878 .870,93$ & 0,9352 & 93,52 & Sangat Tinggi \\
\hline 2 & 2009 & Rp. 390.247.191.102,00 & Rp. 407.069.964.916,07 & 0,9586 & 95,86 & Sangat Tinggi \\
\hline 3 & 2010 & Rp. 406.552.501.953,00 & Rp. 446.819.398.413,85 & 0,9098 & 90,98 & Sangat Tinggi \\
\hline 4 & 2011 & Rp. 353.630.749.839,00 & Rp. 490.636.327.652,63 & 0,7207 & 72,07 & Sangat Tinggi \\
\hline 5 & 2012 & Rp. 517.135.271.153,00 & Rp. 555.570.392.064,59 & 0,9308 & 93,08 & Sangat Tinggi \\
\hline \multicolumn{4}{|c|}{ Rata-Rata } & 0,891 & 89,1 & Sangat Tinggi \\
\hline
\end{tabular}

Sumber: Data diolah, 2013

\section{Rasio Pertumbuhan}

\section{Perhitungan Rasio Pertumbuhan}

\begin{tabular}{|c|c|c|c|c|c|c|}
\hline \multirow{2}{*}{ No } & \multirow{2}{*}{ Keterangan } & \multicolumn{5}{|c|}{ Tahun Anggaran } \\
\hline & & 2008 & 2009 & 2010 & 2011 & 2012 \\
\hline \multirow[t]{2}{*}{1} & $\begin{array}{l}\text { Pendapatan } \\
\text { Asli Daerah } \\
\end{array}$ & Rp. 17.392.736.281,93 & Rp. $16.822 .773 .814,07$ & Rp. $18.763 .528 .960,85$ & Rp. $25.394 .063 .796,63$ & Rp. 38.435.120.911,59 \\
\hline & Pertumbuhan & - & $3,27 \%$ & $11,53 \%$ & $35,33 \%$ & $51,35 \%$ \\
\hline \multirow[t]{2}{*}{2} & Total Pendapatan & Rp. $369 \cdot 257.878 .870,93$ & Rp. 407.069.964.916,07 & Rp. $446.819 .398 .413,85$ & Rp. $490.636 .327 .652,63$ & Rp. 555.570.392.064,59 \\
\hline & Pertumbuhan & - & $10,24 \%$ & $9,76 \%$ & $9,80 \%$ & $13,23 \%$ \\
\hline \multirow[t]{2}{*}{3} & $\begin{array}{l}\text { Belanja } \\
\text { Rutin (Operasi) } \\
\end{array}$ & Rp. $287.386 .205 .855,00$ & Rp. 298.977.031.703,60 & Rp. $343.331 .542 .956,00$ & Rp. $380.005 .130 .183,00$ & Rp. $409.011 .702 .380,00$ \\
\hline & Pertumbuhan & - & $4,03 \%$ & $14,83 \%$ & $10,68 \%$ & $7,63 \%$ \\
\hline \multirow[t]{2}{*}{4} & $\begin{array}{l}\text { Belanja } \\
\text { Pembangunan } \\
\text { (Modal) }\end{array}$ & Rp. 78.762.098.123,00 & Rp. $96.790 .461 .513,00$ & Rp. 113.573.131.025,00 & Rp. 103.257.610.472,00 & Rp. 129.165.574.193,00 \\
\hline & Pertumbuhan & - & $22,88 \%$ & $17,33 \%$ & $9,08 \%$ & $25,09 \%$ \\
\hline
\end{tabular}

Sumber: Data diolah, 2013 


\section{Hasil Pembahasan}

- Rasio Kemandirian selama lima tahun terakhir yang menghasilkan jumlah rata-ratanya sebesar 5,00\% dengan pola hubungan yang instruktif. Dari hasil tersebut, tergambar dengan jelas masih besarnya ketergantungan pemerintah Kota Bitung terhadap sumber-sumber dana bantuan dari pihak ekstern, baik dari pemerintah pusat maupun dari pemerintah provinsi, dengan komponen bantuan terbesar adalah Dana Alokasi Umum (DAU) dan Dana Alokasi Khusus (DAK).

- Rasio Derajat Desentralisasi Fiskal selama lima tahun terakhir menghasilkan jumlah rata-rata sebesar 5,02\% dengan kemampuan keuangan yang masih sangat kurang. Artinya pemerintah Kota Bitung belum mampu membiayai pengeluarannya sendiri karena masih kurangnya penerimaan yang diperoleh berdasarkan Pendapatan Asli Daerah (PAD).

- Rasio Keserasian selama lima tahun terakhir menunjukkan rata-rata belanja rutin (operasi) sebesar 76,5\% dan 30,32\% untuk belanja pembangunan (modal). Artinya pemerintah Kota Bitung lebeih memprioritaskan pengeluarannya pada belanja rutin dibandingkan dengan belanja pembangunan.

- Rasio Indeks Kemampuan Rutin selama lima tahun terakhir menunjukkan rata-rata sebesar 6,64\% dengan kemampuan keuangan sangat rendah. Artinya PAD belum mampu membiayai belanja rutin yang dilakukan pemerintah Kota Bitung.

- Rasio ketergantungan selama lima tahun terakhir menunjukkan rata-rata sebesar 89,1\% dengan kemampuan keuangan sangat tinggi. Artinya pemerintah Kota Bitung masih sangat bergantung pada pendapatan yang diterima diluar PAD dan sangat kurangnya dana dari daerah sendiri untuk membiayai kebutuhan daerahnya.

- Berdasarkan rasio pertumbuhan, PAD mengalami pertumbuhan dari tahun 2008-2012 yang artinya mengalami pertumbuhan positif. Total pendapatan mengalami penurunan dari tahun 2009-2010 dan pertumbuhan dari tahun 2010-2012. Belanja rutin mengalami pertumbuhan pada tahun 2009-2010 dan penurunan dari tahun 2010-2012. Dan belanja pembangunan mengalami penurunan dari tahun 2009-2011 kemudian mengalami pertumbuhan pada tahun 2012. Maka total pendapatan, belanja rutin dan belanja pembangunan mengalami pertumbuhan yang positif juga negatif karena pertumbuhan setiap komponen mengalami peningkatan dan penurunan dari setiap periode berjalan. Artinya, pemerintah Kota Bitung belum mampu mempertahankan pertumbuhannya dari periode yang satu ke periode berikutnya.

\section{Kesimpulan}

Pada bab sebelumnya telah diuraikan hasil penelitian dan pembahasan tentang tingkat kemampuan keuangan daerah dalam pelaksanaan otonomi daerah tahun anggaran 2008-2012 di Kota Bitung. Berdasarkan hasil penelitian dan hasil analisis data dapat ditarik kesimpulan bahwa tingkat kemampuan keuangan daerah Kota Bitung belum mampu mendukung pelaksanaan otonomi daerah untuk periode 2008-2012.

\section{Saran}

Berdasarkan hasil analisis data dan kesimpulan, penulis mencoba mengajukan beberapa saran. Saran-saran tersebut adalah sebagai berikut:

1. Pelaksanaan otonomi daerah sebagaimana dinyatakan dalam UU Nomor 32 tahun 2004, sangat diperlukan kemandirian keuangan daerah agar tingkat ketergantungan keuangan daerah kepada pemerintah pusat dapat dikurangi melalui intensifikasi Pendapatan Asli Daerah yang dilakukan oleh masing-masing daerah.

2. Pemerintah Kota Bitung diharapkan lebih mempertimbangkan belanja daerahnya terhadap belanja pembangunan untuk menunjang kesejahteraan rakyat.

3. Pemerintah Kota Bitung diharapkan memacu pengembangan BUMD yang dapat meningkatkan PAD.

4. Pemerintah Kota Bitung diharapkan lebih mampu untuk mempertahankan pertumbuhannya khusus untuk belanja pembangunan.

\section{DAFTAR PUSTAKA}

Darise, Nurlan. 2008. Akuntansi Keuangan Daerah. Akuntansi Sektor Publik. Jakarta: PT Indeks.

Halim, Abdul. 2007. Akuntansi dan Pengendalian Pengelolaan Keuangan Daerah. Edisi Revisi. Yogyakarta: UPP STIM YKPN.

Halim, Abdul. 2007. Akuntansi Sektor Publik. Akuntansi Keuangan Daerah. Edisi 3. Jakarta: Salemba Empat. 
Mahmudi, 2006, Forum Dosen Akuntansi Sektor Publik : Standar Akuntansi Pemerintahan. Edisi Pertama. Yogyakarta: BPFE.

Mahmudi, 2007, Analisis Laporan Keuangan Pemerintah Daerah. Yogyakarta: UPP STIM YKPN.

Mardiasmo, 2002. Akuntansi Sektor Publik. Yogyakarta: Andi.

Purwanti, Rita Eni dan Indah Nugraheni, 2001. Siklus Akuntansi. Kanisius. Yogyakarta.

Sugianto, 2007. Pajak dan Retribusi Daerah, Pengelolaan Pemerintah Daerah dalam Aspek Keuangan, Pajak, dan Retribusi Daerah. Cikal Sakti. Jakarta.

Tangkilisan, Hessel. 2007. Manajemen Publik. Jakarta: Grasindo.

Tim Redaksi Nuansa Aulia. 2009. Otonomi Daerah. Nuansa Aulia. Bandung. 